\title{
NUMBER OF CASES OF TYPE 1 AND 2 DIABETES DIAGNOSED IN AMAPÁ BETWEEN 2007 AND 2012
}

\section{ORIGINAL ARTICLE}

SOUZA, Kauê de Melo', FACCO, Lucas², FECURY, Amanda Alves³, ARAÚJO, Maria Helena Mendonça de ${ }^{4}$, OLIVEIRA, Euzébio de ${ }^{5}$, DENDASCK, Carla Viana ${ }^{6}$, SOUZA, Keulle Oliveira da ${ }^{7}$, DIAS, Claudio Alberto Gellis de Mattos ${ }^{8}$

SOUZA, Kauê de Melo. Et al. Number of cases of type 1 and 2 diabetes diagnosed in Amapá between 2007 and 2012. Revista Científica Multidisciplinar Núcleo do Conhecimento. Year 05, Ed. 12, Vol. 01, pp. 18-26. December 2020. ISSN: 2448-0959, Access Link:

https://www.nucleodoconhecimento.com.br/health/diabetes-cases, DOI: 10.32749/nucleodoconhecimento.com.br/health/diabetes-cases

\section{ABSTRACT}

Diabetes mellitus is a succession of different types of disorders in metabolism that are characterized by causing a high rate of blood sugar. Because it is a disease with genetic factors type 1 diabetes has as main risk factor heredity, while type 2 diabetes besides these factors, includes obesity, high blood pressure, poor food education and advancing age. This study aims to show the number of cases of type 1 and 2 diabetes diagnosed in Amapá with the variables gender, age group, sedentary

\footnotetext{
${ }^{1}$ Mining Technician, as a minister at the Federal Institute of Amapá (IFAP).

${ }^{2}$ Student of the Medical Course of the Federal University of Amapá (UNIFAP).

${ }^{3}$ Biomedical, PhD in Tropical Diseases, Professor and researcher of the Medical Course of the Federal University of Amapá (UNIFAP).

${ }^{4}$ Physician, Professor and researcher of the Medical Course of the Federal University of Amapá (UNIFAP).

${ }^{5}$ Biologist, PhD in Topical Diseases, Professor and researcher of the Physical Education Course of the Federal University of Pará (UFPA).

${ }^{6}$ Theologian, PhD in Psychoanalysis, researcher at the Center for Research and Advanced Studies - CEPA.

${ }^{7}$ Sociologist, Master's student in Anthropic Studies in the Amazon, Member of the Research Group "Laboratory of Education, Environment and Health" (LEMAS/UFPA).

${ }^{8}$ Biologist, PhD in Theory and Behavior Research, Professor and researcher of the Graduate Program in Professional and Technological Education (PROFEPT), Federal Institute of Amapá (IFAP).
}

RC: 66735

Available in: https://www.nucleodoconhecimento.com.br/health/diabetes-cases 
lifestyle, overweight, smoking, between 2007 and 2012. The data for the research were taken from the computer department of SUS, DATASUS (http://datasus.saude.gov.br). Type 1 and 2 diabetes mellitus (DM1 and DM2) are diseases that are tied to disturbances in production or in the efficient use of insulin. Smoking, as well as sedentary lifestyle and overweight are important risk factors for the development of DM2. Type 2 diabetes mellitus provides the development of various organic nerve lesions. In addition, DM2, through its chronicity, enables the development of retinopathies, nephropathies and other conditions negative to the individual's health.

Keywords: Amapá, Diabetes Mellitus, overweight, sedentary lifestyle, smoking.

\section{INTRODUCTION}

Diabetes mellitus is a succession of different types of metabolism disorders that are characterized by causing a high rate of blood sugar, usually related to the absence of insulin or deficiency in the absorption of the same by the body (ADA, 2014).

Type 1 diabetes (DM1) occurs when the body attacks the cells responsible for producing insulin leading to complete deficiency of this hormone in the body. It occurs less often because it is usually linked to genetic factors. Type 2 diabetes (DM2) happens when the body cannot absorb the insulin produced in the body due to the pancreas's inability to produce it in sufficient quantity. This usually occurs when the individual has a history of poor diet and sedentary lifestyle and is more easily acquired if he/she has a hereditary tendency to the disease (BRASIL, 2006; MORA et al., 2015).

Symptoms of type 1 and 2 diabetes include increased urine volume, excess headage, increased hunger, weight loss, tiredness, mood swings, hypoglycemia, and hyperglycemia. Type 2 diabetes may not present symptoms for several years, with the increase in insulin deficiency being the fuse for the evolution of this type (UFRGS, 2016; NOGUEIRA et al., 2015).

RC: 66735

Available in: https://www.nucleodoconhecimento.com.br/health/diabetes-cases 
Because it is a disease with genetic factors type 1 diabetes has as main risk factor heredity, while type 2 diabetes besides these factors, includes obesity, high blood pressure, poor food education and advancing age (LIMA et al.; 2014)

Prevention of type 2 diabetes is directly linked to a life with good eating habits and regular physical exercises. Because it is hereditary and autoimmune, it is not how to prevent type 1 diabetes (MAGALHÃES et al., 2017).

Because DM1 is characterized by complete insulin deficiency, insulin therapy is shown to be the best treatment. DM2 because it is an inability of the body to produce or absorb enough insulin, the treatment is dedicated to maintaining glycemic control of the body, which includes both oral medications and physical exercises together with a balanced diet (UFRGS, 2016; SANTOS; FREITAS; PINTO, 2014).

In 2012 the number of worldwide cases of diabetes was approximately 200 million, while cases in Brazil were close to 10 million (BRASIL, 2012).

\section{GOAL}

Show the number of cases of type 1 and 2 diabetes diagnosed in Amapá with the variables gender, age group, sedentary lifestyle, overweight, smoking, between 2007 and 2012.

\section{METHOD}

Data taken from the computer department of SUS, DATASUS (http://datasus.saude.gov.br), following the following steps: first, the Tab "access to information" was selected, followed by the option "health information (TABNET)" soon after the sub-option "epidemiological and morbidity", then the option group "Hypertension and diabetes (HIPERDIA)" was accessed. The following icon "Hyperdia- Registration and Monitoring of Hypertensive and Diabeticpatients - since 2002" the tab "select the option or click on the map" was selected and if you selected

RC: 66735

Available in: https://www.nucleodoconhecimento.com.br/health/diabetes-cases 
the option "Amapá", for data collection, the "sex" option was selected in the row field, in the column field the "not active" option, and in the content field the option "type 2 diabetes" , after "available periods" data were collected from 2007 to 2012; the same period used for all other collections. The "age group" option was selected in the line field, in the column field the "not active" option, and in the content field the "type 2 diabetes" option. The "sex" option was selected in the row field, in the column field the "not active" option, and in the content field the "type 1 diabetes" field. The age group option was selected in the row field, in the column field the "not active" option, and in the content field the "type 1 diabetes" option. The "year" option was selected in the row field, in the column field the "not active" option, and in the content field the "type 1 diabetes" field. The "year" option was selected in the row field, in the column field the "not active" option, and in the content field the "type 2 diabetes" field. The "smoking" option was selected in the row field, in the column field the "non-active" option, and in the content field the "type 1 diabetes" field. The "smoking" option was selected in the row field, in the column field the "non-active" option, and in the content field the "type 2 diabetes" option. The data was compiled within the Excel application, a component of the Microsoft Corporation Office suite. The bibliographic research was carried out in scientific articles, using computers from the computer laboratory of the Federal Institute of Education, Science and Technology of Amapá, Macapá Campus, located at: Rodovia BR 210 KM 3, s/n - Bairro Brasil Novo, ZIP Code: 68.909-398, Macapá, Amapá, Brazil.

\section{RESULTS}

Figure 1 shows the number of confirmed cases of diabetes in the state of Amapá between 2007 and 2012. More cases of type 2 diabetes than type 1 have been diagnosed.

RC: 66735

Available in: https://www.nucleodoconhecimento.com.br/health/diabetes-cases 
Figure 1 Shows the number of confirmed cases of diabetes in the state of Amapá between 2007 and 2012.



Figure 2 shows the number of confirmed cases of type 1 and 2 diabetes in the state of Amapá between 2007 and 2012 according to gender. The highest number of diagnoses of type 1 and 2 diabetes was in women.

RC: 66735

Available in: https://www.nucleodoconhecimento.com.br/health/diabetes-cases 
Figure 2 Shows the number of confirmed cases of type 1 and 2 diabetes in the state of Amapá between 2007 and 2012 according to gender.

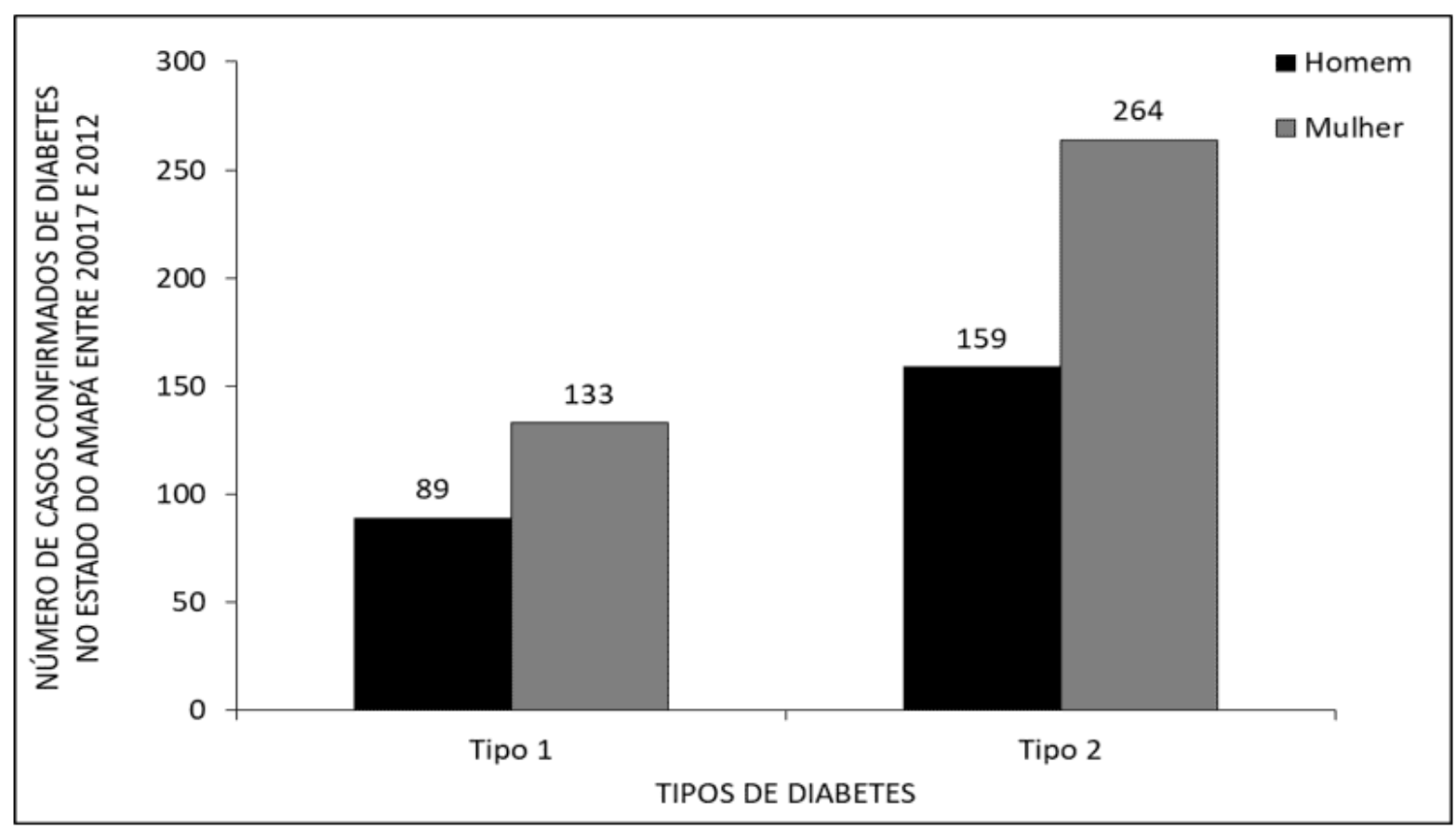

Figure 3 shows the number of confirmed cases of type 1 and 2 diabetes in the state of Amapá between 2007 and 2012 according to age group. The highest number of diagnoses of type 1 and 2 diabetes was of people aged 30-59 years, while the lowest was of people up to 29 years of age.

RC: 66735

Available in: https://www.nucleodoconhecimento.com.br/health/diabetes-cases 
Figure 3 Shows the number of confirmed cases of type 1 and 2 diabetes in the state of Amapá between 2007 and 2012 according to age group.

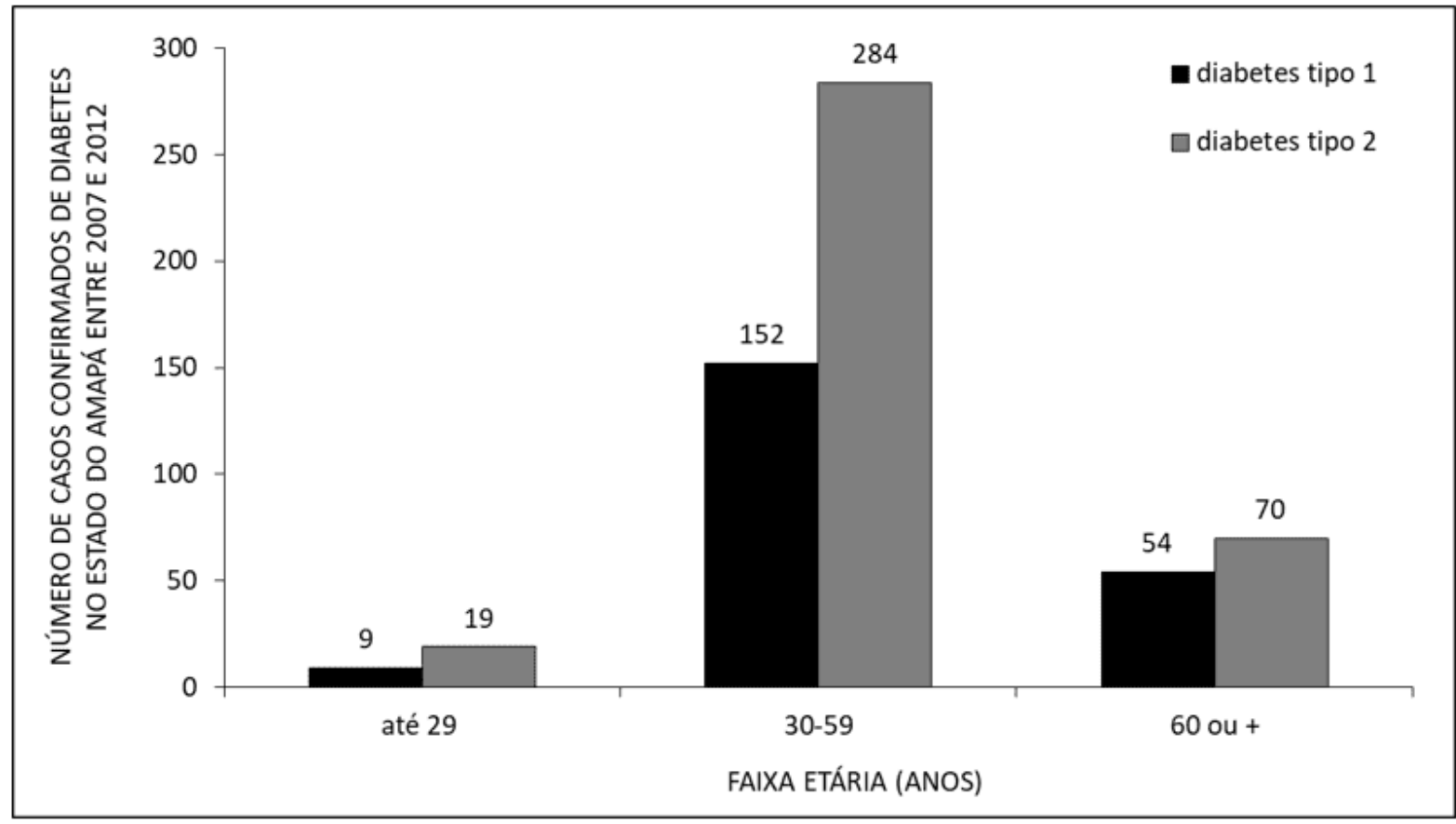

Figure 4 shows the number of confirmed cases of type 1 and 2 diabetes in the state of Amapá between 2007 and 2012 according to weight. The highest number of diagnosed cases of type 1 and 2 diabetes was of people without overweight.

RC: 66735

Available in: https://www.nucleodoconhecimento.com.br/health/diabetes-cases 
Figure 4 Shows the number of confirmed cases of type 1 and 2 diabetes in the state of Amapá between 2007 and 2012 according to weight.



Figure 5 shows the number of confirmed cases of type 1 and 2 diabetes in the state of Amapá between 2007 and 2012 according to sedentary lifestyle. The highest number of diagnoses of type 1 and 2 diabetes was of non-sedentary people.

RC: 66735

Available in: https://www.nucleodoconhecimento.com.br/health/diabetes-cases 
Figure 5 Shows the number of confirmed cases of type 1 and 2 diabetes in the state of Amapá between 2007 and 2012 according to sedentary lifestyle.

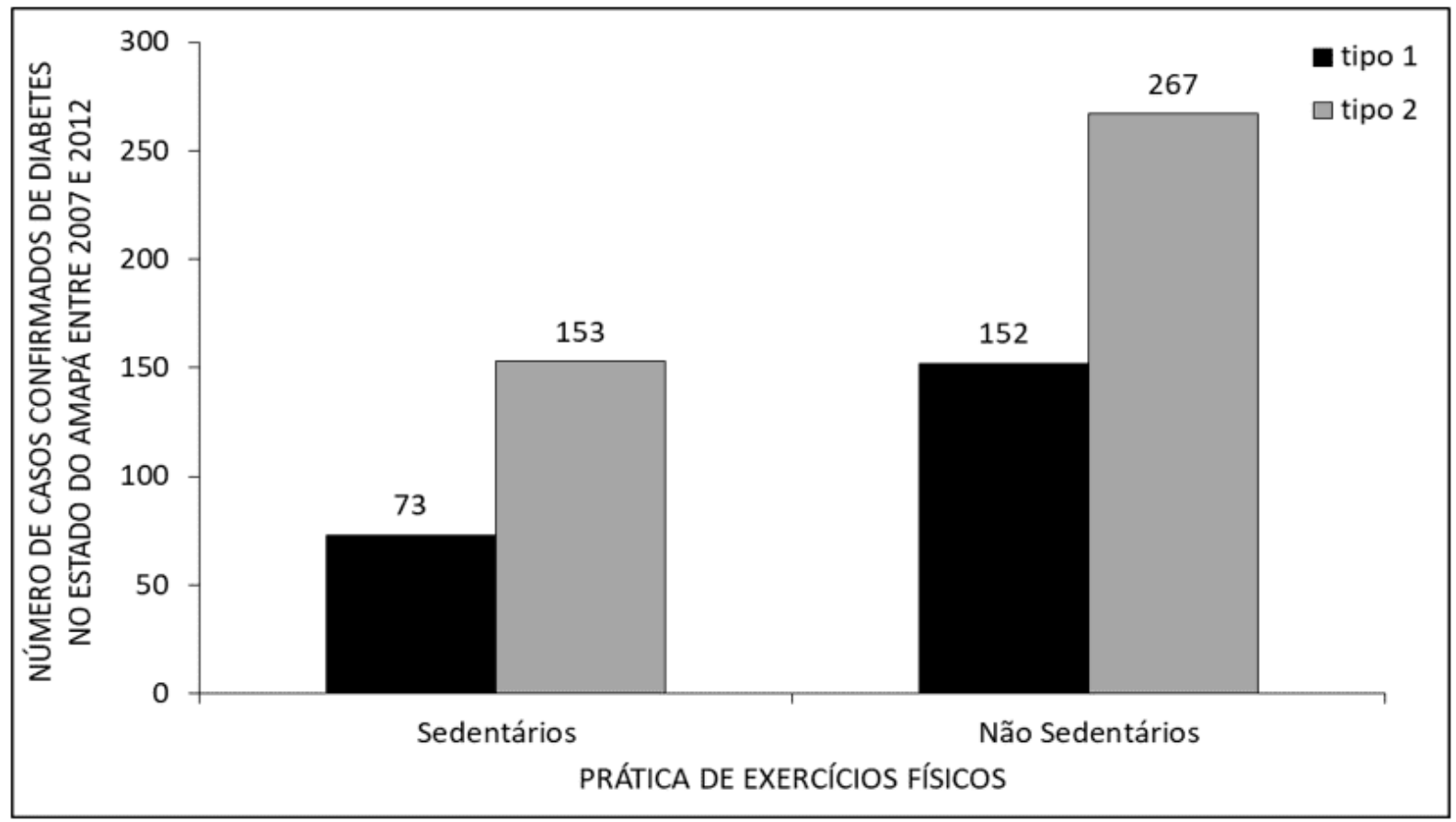

Figure 6 shows the number of confirmed cases of type 1 and 2 diabetes in the state of Amapá between 2007 and 2012 according to smoking. The highest number of diagnoses of type 1 and 2 diabetes was of non-smokers.

RC: 66735

Available in: https://www.nucleodoconhecimento.com.br/health/diabetes-cases 
Figure 6 Shows the number of confirmed cases of type 1 and 2 diabetes in the state of Amapá between 2007 and 2012 according to smoking.



\section{DISCUSSION}

Type 2 diabetes mellitus (DM2) is one of the main Chronic Noncommunicable Diseases (NCDs), and represents about $90 \%$ of all current cases of diabetes (COSTA et al., 2017). This factor is very associated with the prevalence of obesity, since this is one of the main risk factors for the development of DM2. The number of obese patients (who have DM2) who receive specific and properly structured care so that they can control their weight is very low, and, therefore, it is noted that this problem constitutes an important risk factor for individual health, because obesity represents a risk to the development of various diseases, such as cardiovascular diseases, influencing in a largely negative way the control of DM2 (LIMA et al. , 2015).

It is noted that the prevalence of diabetes among women is high, and there are several factors to be analyzed for this finding. In a study conducted in the

RC: 66735

Available in: https://www.nucleodoconhecimento.com.br/health/diabetes-cases 
municipality of São Leopoldo, In Rio Grande do Sul, numerous parameters and variables were evaluated for this problem. It was observed that the highest prevalence of diabetes occurred among women who have: age between 40 and 49 years, married marital status, income below 1 minimum wage, 1 to 3 children, smoking practice, Systemic Arterial Hypertension (SAH), and other factors, such as obesity, which is the most important risk factor for DM2 (DIAS-DA-COSTA et al., 2020).

Type 1 diabetes mellitus (DM1), also called insulin-dependent diabetes, occurs more frequently in adolescent patients, and its pathophysiology involves the destruction of pancreatic beta cells - responsible for insulin production in the body - and, consequently, leading the body to a deficiency of insulin production, making the individual dependent on the use of synthetic insulin. DM2 usually occurs after 30 years, being more common in individuals between 50 and 60 years. (ABREU, 2017). Its pathophysiology is related to insulin resistance and, therefore, the hypoglycemic action performed by this hormone does not occur adequately, causing increased glucose production by the liver, contributing broadly with the high amount of insulin at blood level (BERTONHI and DIAS, 2018).

Although, between 2007 and 2012, the number of confirmed cases of DM1 and DM2 in Amapá was higher among people without overweight, non-sedentary and nonsmokers, the association between DM2 and these conditions is well known. A large proportion of patients with type 2 diabetes mellitus are obese or overweight. Smoking practice is responsible for the exponential increase in the possibility of the individual developing a neoplasm, being (in isolation) the main cause of cancer worldwide. Diabetes has an intimate link with cancer, since it increases the possibility of developing liver neoplasms, in addition to cancers of the colon, endometrium, breast and pancreas. Thus, the predisposition of diabetic smokers to neoplasms is noted. In addition, sedentary lifestyle is characterized as one of the variables to be considered for the development of DM2. In a study conducted with students from the Federal University of Ceará (UFC), it was noted the vehement lack of regular physical

$\mathrm{RC}: 66735$

Available in: https://www.nucleodoconhecimento.com.br/health/diabetes-cases 
exercise, sometimes justified due to lack of motivation and time, in addition to tiredness coming from the student's daily journey. The absence of daily practice of physical exercises can promote overweight (overweight and obesity), which are risk factors for the development of DM2 (LIMA et al., 2015; HOCAYEN and MALFATTI, 2010; LIMA et al., 2014).

\section{CONCLUSION}

Type 1 and 2 diabetes mellitus (DM1 and DM2) are diseases that are tied to disturbances in production or in the efficient use of insulin. DM1 is a disease whose pathophysiology is not completely known that involves genetic predisposition, combined with environmental factors. DM2, on the other hand, even though it has genetic bases, is very close to the individual's lifestyle, and obesity, overweight and sedentary lifestyle are one of the main risk factors for the development of this pathology.

It is noted that, among diabetics, the prevalence of women is very high. Factors such as age between 40 and 49 years, income below 1 minimum wage, married marital status, 1 to 3 children, smoking practice, Systemic Arterial Hypertension (SAH), and other factors, such as obesity are responsible for this problem.

DM1 occurs more frequently in adolescent patients, and its pathophysiology involves the destruction of pancreatic beta cells, causing in the body a deficiency of insulin production, making the individual dependent on the use of synthetic insulin. DM2 occurs more frequently after 30 years, being more common in individuals between 50 and 60 years, and its pathophysiology is related to insulin resistance and, in view of this, the hypoglycemic action performed by insulin does not occur adequately in the body, causing, as the chronicity of the disease occurs, a series of negative consequences to organisms, with macro and microvascular lesions and among others.

RC: 66735

Available in: https://www.nucleodoconhecimento.com.br/health/diabetes-cases 
Smoking, as well as sedentary lifestyle and overweight are important risk factors for the development of DM2. Type 2 diabetes mellitus provides the development of various organic nerve lesions. In addition, DM2, through its chronicity, enables the development of retinopathies, nephropathies and other conditions negative to the individual's health.

\section{REFERENCES}

ABREU, L. C. S. Diabetes na Terceira Idade. Revista Científica Multidisciplinar Núcleo do Conhecimento, v. 2, p. 111-131, 2017.

ADA. American Diabetes Association; Diagnosis and Classification of Diabetes Mellitus; Diabetes Care, Volume 37, Supplement 1, January 2014.

BERTONHI, L. G.; DIAS, J. C. R. Diabetes mellitus tipo 2: aspectos clínicos, tratamento e conduta dietoterápica. Revista Ciências Nutricionais Online, v. 2, n. 2, p. 1-10, 2018.

BRASIL. Ministério da Saúde. Secretaria de Atenção à Saúde. Departamento de Atenção Básica. Diabetes Mellitus / Ministério da Saúde, Secretaria de Atenção à Saúde, Departamento de Atenção Básica. - Brasília : Ministério da Saúde, 2006.

BRASIL. Portal Brasil. Diabetes traz consequências graves se não for controlado. 2012. disponível em: <http://www.brasil.gov.br/saude/2012/04/diabetes>. Acessado Em: 19/09/2017.

CORTEZ. D.N; Reis, I.A; Souza, D.A.S; Macedo, M.M.L; Torres H.C Complicações e o tempo de diagnóstico do diabetes mellitus na atenção primária Acta Paulista de Enfermagem, vol. 28, núm. 3, 2015, pp. 250-255.

COSTA, A. F.; FLOR, L. S.; CAMPOS, M. R.; OLIVEIRA, A. F.; COSTA, M. F. S.; SILVA, R. S.; LOBATO, L. C. P.; SCHRAMM, J. M. A. Carga do diabetes mellitus tipo 2 no Brasil. Cad. Saúde Pública, v. 33, n. 2, p. 1-14, 2017.

$\mathrm{RC}: 66735$

Available in: https://www.nucleodoconhecimento.com.br/health/diabetes-cases 
DIAS-DA-COSTA, J. S.; SILOCCHI, C.; SCHWENDLER, S. C.; MORIMOTO, T.; MOTTIN, V. H. M.; PANIZ, V. M. V.; BAIRROS, F. S.; OLINTO, M. T. A. Prevalência de diabetes mellitus autorreferido em mulheres e fatores associados: estudo de base populacional em São Leopoldo, Rio Grande do Sul, 2015. Epidemiol. Serv. Saude, v. 29, n. 2, p. 1-12, 2020.

HOCAYEN, P. A. S.; MALFATTI, C. R. M. Tabagismo em pacientes diabéticos: predisposição às doenças crônico-degenerativas e neoplasia. Cinergis, v. 11, n. 2, p. 19-25, 2010.

LIMA, A. C. S.; ARAÚJO, M. F. M.; FREITAS, R. W. J. F.; ZANETTI, M. L.; ALMEIDA, P. C.; DAMASCENO, M. M. C. Fatores de risco para diabetes mellitus tipo 2 em universitários: associação com variáveis sociodemográficas. Rev. LatinoAm. Enfermagem, v. 22, n. 3, p. 484-490, 2014.

LIMA, L. L.; SÁ, A. D.; FIGUEIREDO, A. S.; MUÑOZ, R. L. S. Prevalência de sobrepeso e obesidade em diabéticos tipo 2 atendidos no ambulatório de Endocrinologia de um Hospital Universitário. Rev Soc Bras Clin Med, v. 13, n. 4, p. 251-256, 2015.

MORA, G.P.C.; Abascal I.C.; Sanabria, G. Sobrepeso, obesidad y diabetes mellitus 2 en adolescentes de América Latina en 2000-2010;Revista Cubana de Medicina General Integral. v. 31, n. 3, 217-231, 2015.

SANTOS, M. S, Freitas, N. M; Pinto, F. O; O DIABETES MELLITUS TIPO 1 E TIPO 2 E SUA EVOLUÇÃO NO MUNICÍPIO DE QUISSAMÃ-RJ; Revista Científica Interdisciplinar, vol 1,No 1, 2014.

UFRGS. RegulaSUS. Diabetes Mellitus. Disponível em: $<$ https://www.ufrgs.br/telessauders/documentos/protocolos_resumos/endocrino_resu mo_diabetes_TSRS_20160324.pdf >.Acesso em: 19/09/2017.

Submitted: December, 2020.

RC: 66735

Available in: https://www.nucleodoconhecimento.com.br/health/diabetes-cases 
Approved: December, 2020.

RC: 66735

Available in: https://www.nucleodoconhecimento.com.br/health/diabetes-cases 